\title{
Usposabljanje včifeljev za razvijanje komunikacijskih spretnosti
}

Tatjana Kadunc

\author{
Zadovoljujoči medsebojni odnosi med učiteljem in učenci so prvi pogoj za uspeh pri \\ učenju, za psihično zdravje in osebno srečo. \\ Učiteljeva zmožnost ustvarjanja in ohranjevanja medsebojnih odnosov z učenci, ki te- \\ meljijo na soodvisnosti in sodelovanju, je eden glavnih znakov uspešnega psihičnega \\ delovanja tako učitelja kot učencev.
}

\section{Pomen komunikacijskih spreinosti za učifelievo poklieno delo}

Spretnosti $\mathrm{v}$ medsebojnih odnosih so $\mathrm{v}$ veliki meri rezultat učenja v zgodnjem otroštvu, pozneje pa jih izvajamo bolj ali manj avtomatično in o njih ne premišljujemo. Večina ljudi ima na tem področju večje ali manjše primanjkljaje. Večino le-teh lahko nadomestimo $\mathrm{z}$ načrtnim učenjem komunikacijskih spretnosti.

Stevilne raziskave so pokazale, da se spretnosti medsebojnih odnosov lahko uspešno naučijo tudi odrasli. Čeprav je za učitelje spretnost v komuniciranju sestavni del njihove poklicne dejavnosti, smo učenju te spretnosti do sedaj posvečali le malo pozornosti. Še daleč smo od tega, da bi sistematično učenje in razvijanje komunikacijskih spretnosti postalo del splošnega izobraževalnega programa, kot je to značilno za mnoge razvite dežele.

\section{Kako izobraževahi učilelje, da bodo postali uspešnejs̆i v svojem vzgojno- izobraževalnem delu}

Postavlja se vprašanje, kako izobraževati učitelje, da bodo temeljito obvladali najrazličnejše izobraževalne in vzgojne oblike, metode in postopke; da jih bodo smotrno in elastično vključevali v pouk in druge dejavnosti, da bodo ustrezno ravnali tako $\mathrm{v}$ običajnih kot $\mathrm{v}$ novih in obremenjujočih situacijah (kot npr. pri delu s težavnim razredom ali s problematičnim učencem, preštevilčnim razredom), da bodo pri tem uporabili teoretično znanje in ga povezali z bogatimi vsakdanjimi izkušnjami, da se bodo naučili povezovati teorijo s prakso.

Odgovor na to vprašanje so iskali:

1. nekateri $v$ natančnem izvoru in sistematičnem posredovanju teoretičnih znanj, ki jih učitelj potrebuje (strokovna, pedagoškopsihološka, specialno-didaktična): s seminarji, študijem literature;

2. drugi spet v praktičnem uvajanju v učne metode in postopke (kako uciti): bodisi na celovitejšsem makronivoju (hospitacije in nastopi) bodisi v novejšem času s sistematičnim treningom ali vajo $v$ učnih spretnostih (mikropouk in njegove različice);

3. tretji v razvoju, ki naj bi z različnimi oblikami skupinskega dinamičnega treninga, navezanega na poklicno delovanje in vlogo, izboljšal udeleženčevo samozavedanje in občutjjivost za socialne odnose.
Vsi navedeni pristopi so enostransko usmerjeni bodisi v teorijo bodisi v prakso, pri tem pa so nesposobni povezati teorijo $\mathrm{z}$ vsakodnevno učiteljevo prakso. Ker se že nekaj časa ukvarjam z izobraževanjem učiteljev, ugotavljam, da se pri učiteljih pojavlja določeno protislovje, razklanost med teoretičnimi znanji, abstrakcijami, ki si jih učitelji pridobijo v okviru dodiplomskega in podiplomskega izobraževanja, in med pomeni, ki jih pripisujejo konkretnim vsakdanjim šolskim situacijam. Ker je naš šolski sistem še vedno v veliki meri preveč teoretično zasnovan, učitelji v neposrednem srečanju s konkretno šolsko prakso teorije ne znajo učinkovito prenesti $\mathrm{v}$ prakso. Odpravljanje omenjenega protislovja bi zahtevalo prevelik miselni in čustveni napor, zato ga učitelji večinoma puščajo pri miru, živijo $\mathrm{z}$ nekakšnim dvojnim sistemom dojemanja šolske stvarnosti.

\section{Pomen izkustvenega učenja za razvoj komunikacijskih spretnosti}

Spretnosti komuniciranja $\mathrm{z}$ ljudmi se učitelji ne morejo naučiti le $\mathrm{z}$ branjem ustrezne literature. Potrebno je izkustveno učenje, podobno kot to velja za učenje drugih spretnosti (pisanje, branje, vožnja avtomobila).

lzkustveno učenje razumemo kot proces progresivnega, trajnega spreminjanja posameznika na osnovi izkušenj, pri čemer obstoječe znanje, pa tudi stališca, pričakovanja, čustva posameznika in njegov socialni okvir vplivajo na to, česa se bo naučil in kako. Subjekt, ki se uči, dobiva torej aktivnejšo, pomembnejšo vlogo. Osnovna ideja tega učenja je, da se najbolje naučimo tistih stvari, ki jih sami izvajamo, in če smo dejansko aktivni. Naše lastno doživljanje je cilj učenja in razvoja. To ni samo droben delček izobraževanja, temveč masiven pojem - centralni proces človekove adaptacije $v$ njegovo socialno in fizično okolje. Vsebuje integrativne funkkcije vsega organizma - mišljenja, čustev, zaznavanja in vedenja. Vključuje celo življenje.

Izkustveno učenje $\mathrm{z}$ miselno, čustveno in dejavno aktivnostjo udeležence neposredno osebno vključuje $v$ učni proces. $S$ tem omogoča visoko stopnjo motivacije, dviga njihova osebna prizadevanja, zavedanja, omogoča vživljanje v druge ljudi, razgme vso različnost izkušenj posameznikov in s tem pomaga spreminjati utrjena stališca in vpliva na ravnanje. Pomaga pridobiti razne spretnosti, zlasti komunikacijske. Izkustveno učenje pomaga naše kognitivno vedenje oplemenititi $z$ znanstvenimi teorijami, naše praktično ravnanje povezati s teoretičnimi znanji. Vpli- 
va torej na spremembo našega vedenja in ravnanja, ki ga oplemeniti in postavi na višji nivo.

Tako učenje je povezano $\mathrm{s}$ konkretno življenjsko situacijo $\mathrm{v}$ dvojnem smislu:

1. problem naj bo za posameznika osebno pomemben, naj izhaja iz njegovih življenjskih izkušenj in protislovij, ki jih občuti;

2. neposredna učna situacija (prostor, časovna razporeditev, socialno-emocionalne okoliščine - učna klima) mora biti ugodna za tako učenje.

Sprošceni odnosi (v nasprotju z napetimi avtoritarnimi, hierarhičnimi ali uradnimi) so pomembni tudi zato, ker signifikantno učenje pogosto privede do strukturiranja prejßnjih, v osebnosti zakoreninjenih shem spoznavanja, kako je naporen proces, ki sam po sebi ogroža osebnost.

Pomembna komponenta izkustvenega učenja je tudi medsebojna komunikacija ljudi, ki se ukvarjajo $\mathrm{z}$ istim problemom. Ta komunikacija se ne omejuje le na razgovor o problemu, ampak na skupno razmišljanje in tudi delovanje. Izkustveno učenje je hkrati socialno učenje, ki zmanjšuje razliko med vlogama učenca in učitelja. Oba sta udeležena pri enakopravnem medsebojnem sodelovanju in iskanju rešitev.

\section{Načrt za učifeljevo usposabljanje}

Običajno mora načrt za učiteljevo usposabljanje vsebovati:

1. ugotavljanje prevladujočih metod, oblik dela, stila, sistema poučevanja, $\mathrm{ki}$ jih ima udeleženec treninga že razvite, in opredelitev tistih, ki jih bo v času usposabljanja prevzel in jih preizkusil v svojem učno-vzgojnem delu. Gre za presojo, v cem se predlagani novi postopek, ki ga bo učitelj prevzel, razlikuje od tistega, ki ga sicer uporablja pri svojem delu $\mathrm{z}$ učenci;

2. vrsto in obseg pedagoško-psihološkega strokovnega znanja, ki ga bo učitelj potreboval za svoje usposabljanje;

3. učne spretnosti, ki jih mora učitelj razviti, da bo pri svojem delu $\mathrm{z}$ učenci uspešen;

4. upoštevanje glavnih značilnosti udeležencev usposabljanja, torej učiteljev;

5. upoštevanje značilnosti učencev (starost).

Poleg tega se morajo učitelji - udeleženci usposabljanja usposobiti za to, da znajo sami načrtovati, spremljati in ocenjevati svoj program, kar poudarja akcijsko raziskovanje. Potrebno je omeniti dejstvo, in sicer, da so najbolj običajne oblike usposabljanja v učiteljevem izobraževanju frontalno oblikovana predavanja, ki temeljijo na srednješolskem načinu dela, to znanje pa učitelji prenesejo, ali pa tudi ne, v svoje praktično vzgojno-izobraževalno delo $z$ učenci. Povratno informacijo, ali je njihovo praktično delovanje zadovoljivo ali ne, pa učitelju nudijo samo šolske svetovalne službe (ravnatelj, pedagog, psiholog) - pa še to redko zaradi njihove preobremenjenosti - $\mathrm{v}$ izrednih primerih kolegi učitelji. Učitelji - udeleženci usposabljanja - se srečujejo s številnimi vzgojno-izobraževalnimi problemi pri proučevanju, saj predavanja niso konkretizirana.

\section{Izkušnje s področja usposabljanja učifeljev za uspešnejšo komunikacij॰}

Pred leti sem izvedla raziskavo, v okviru katere sem usposabljala pet osnovnošolskih učiteljev za uspešnejšo komunikacijo. Usposabljanje je trajalo šest mesecev. Želela sem ugotoviti, ali in kako bodo učitelji v dopolnilnem izobraževanju s pomočjo uspo- sabljanja za uspešnejšo komunikacijo izboljšali svojo besedno in nebesedno komunikacijo. Posebej me je zanimalo, kakšne spremembe bodo pod vplivom posameznih eksperimentalnih intervencij nastale $v$ učiteljevem načinu razmišljanja, $v$ njegovi stopnji zavedanja in $v$ praktični uporabi novih spoznanj pri delu $\mathrm{z}$ učenci ter kako bo učiteljevo ozaveščeno vedenje vplivalo na učence, ali bo prispevalo h konstruktivnejši socialno-emocionalni klimi.

Na začetku svojega dela sem želela $z$ metodo progresivnega podvajanja ugotoviti, s kakšnimi problemi v učno-vzgojnem delu $\mathrm{z}$ učenci so se učitelji do sedaj srečevali, kako so jih reševali in kakšni so bili učinki ter kakšna so njihova pričakovanja v zvezi z našim usposabljanjem, kakšna znanja in spretnosti bi si želeli pridobiti.

Skupno smo oblikovali okvimi program dela. S takšnim zacetkom dela so bili učitelji zadovoljni, saj so bili soustvarjalci programa za uspešnejšo komunikacijo.

Skupinska srečanja v prvem delu usposabljanja za uspešnejšo komunikacijo so pripomogla, da so se učitelji teoretično in praktično seznanili s konkretnimi učnimi spretnostimi v besednem in nebesednem zaznavanju in izražanju. Dovolj poglobljen vpogled $v$ teoretične osnove ustreznih spretnosti je učiteljem omogočil, da so lahko kasneje aktivno sodelovali v urjenju svojih spretnosti. S tem sem se želela izogniti enostranskosti nekaterih behavioristično usmerjenih poskusov, ki usposabljajo udeležence v določenih spretnostih, ne da bi jim dali najprej ustrezen kognitivni okvir. Strukturirane vaje, simulacije, na katerih so učitelji urili svoje spretnosti, so bile večinoma vnaprej pripravljene, delno pa sem določena srečanja prilagodila učiteljevim željam in potrebam.

Zaradi specifičnih problemov, s katerimi so se učitelji srečevali v svojem vzgojno-izobraževalnem delu, sem $z$ vsakim učiteljem posebej izvedla še individualna srečanja. Učitelji so s samoanalizo posnetka svoje učne ure, $\mathrm{z}$ mojimi kritičnimi pripombami in pripombami učencev ozavestili svoje vedenje $v$ razredu. Ugotovili so, kaj dobro obvladajo, česa še ne tako dobro, čemu naj v prihodnosti posvečajo pozornost in kaj naj spremenijo. Spoznali so ustreznost in neustreznost svojih didaktičnih postopkov.

Učiteljem sem pomagala tudi pri razreševanju vzgojne problematike. Z mojo pomočjo so poskušali razrešiti konkretne konflikte s celim razredom ali s posameznimi učenci. V končnem delu usposabljanja so bili ucitelji veliko bolj sproščeni, zaupljivi, motivirani in aktivni. Verjetno je bil vzrok ta, da so lahko $\mathrm{z}$ individualnimi srečanji konkretno razrešili svoje probleme.

Spoznala sem (s pomočjo svojih zapažanj in pripomb učiteljev), da je pri načrtnem razvijanju komunikacijskih spretnosti že delujočih učiteljev nujno potrebno (potem, ko se teoretično in praktično seznanijo $\mathrm{z}$ ustreznimi spretnostmi) znanje praktično preizkusiti v učno-vzgojnem delu. S samoanalizo učnih ur, posnetih na video trak, ter iz pripomb učencev in mentorja lahko ugotovijo svoje prednosti in pomanjkljivosti pri izvajanju ustreznih spretnosti. Izkazalo se je, da je ta zadnja eksperimentalna intervencija $v$ urjenju komunikacijskih spretnosti povzročila spremembe ne samo $v$ učiteljevem razmisljanju, ampak tudi $v$ njegovem ravnanju.

Raziskava je pokazala, da se je po usposabljanju - med snemano učno uro kot tudi med učnimi urami nasploh - učiteljeva besedna in nebesedna komunikacija $v$ mnogih pogledih izboljsala.

Že nekaj časa izvajam usposabljanje vzgojno-izobraževalnih delavcev v okviru stalnega strokovnega izobraževanja. Pedagoški delavci se usposabljajo v besedni komunikaciji ( 24 učnih ur), nebesedni komunikaciji ( 40 učnih ur) ter besedni in nebesedni 
komunikaciji pri učinkovitem reševanju konfliktnih situacij (32 učnih ur).

Pedagoški delavci se najprej seznanijo s teoretičnimi osnovami ustreznih spretnosti besedne in nebesedne komunikacije. Z ustvarjalno diskusijo si medsebojno izmenjujejo izkušnje o njihovi uporabi spretnosti pri vzgojno-izobraževalnem delu. Nato s praktičnimi vajami pod mojim vodstvom in s pomočjo drugih $\mathrm{v}$ skupini spoznavajo in ozaveščajo svoje komunikacijsko vedenje. Odkrivajo svoje prednosti, pomanjkljivosti in vzroke najpogostejših napak, kar vpliva na spremembo njihovega razmišljanja in ravnanja. Preoblikujejo si negativne miselne vzorce, ki jih ovirajo pri učinkovitih medosebnih stikih, zmanjšujejo strah, ki jim preprečuje uresničitev zastavljenih ciljev, razvijajo si pozitivno mišljenje ter se učijo, kako $v$ praksi uporabljati omenjene veščne za razvoj učinkovitejšega vedenja. Vaje potekajo $\mathrm{v}$ prijetnem razpoloženju, učitelji so ves čas aktivni in ustvarjalni. $Z$ vajami si ne razvijajo le omenjenih besednih in nebesednih komunikacijskih spretnosti, temveč tudi večajo samozaupanje, kajti čim več vemo o sebi, večje zaupanje imamo vase.

Moje mnenje je, da je potrebno dobro poznati samega sebe, »delati predvsem na sebi«, tako bomo lažje in bolje opravljali svoje delo in se nasploh v življenju tudi lepše imeli. Najprej moramo pregledati, kaj imamo, šele potem lahko to odstranimo. Nekatere misli, lastnosti imamo radi, zato jih zloščimo, da se svetijo in postanejo še koristnejše. Nekatere je potrebno zamenjati ali popraviti. Nekatere so kot stari časopisi ali stare obleke, ki niso več primeme za nošenje. Te pošljemo proč ali jih vržemo v smeti in jim dovolimo, da za vedno odidejo. Dobro je začeti s tistim, kar nam je najbolj pri srcu. Druga področja se bodo očistila skoraj sama. Na ta način si razvijamo svoj stil komunikacijskega vedenja, ki ustreza naši osebnosti.

Med enim in drugim delom usposabljanja pedagoških delavcev na ustreznem področju je enomesečni premor, da lahko učitelji svoje na novo pridobljene spretnosti in spoznanja prenesejo $\mathrm{v}$ učno-vzgojno prakso. Na drugem delu usposabljanja si učitelji med seboj izmenjajo svoje izkušnje in ob moji pomoči odstranijo morebitne prepreke pri praktičnem izvajanju spretnosti.

\section{Nekaj odmevov pedagoških delavcev po usposabljanju}

- Moja prisotnost na seminarju je spremenila moje razmišljanje in vrednotenje sebe in poglede na druge. Tu sem se prvič srečala s praktičnim načinom dela - bilo mi je zelo všeč. Pričakovala sem dolgo predavanje in neljubo zapisovanje. Že takoj na začetku pa sem se srečala $z$ zanimivo praktično vajo.

- Izkušnje s seminarja sem uporabila pri delu z otroki in starši mojih varovancev. Na roditeljskem sestanku treme skoraj ni bilo, starši so bili prijazni in voljni sodelovati, kar do sedaj ni bilo $\mathrm{v}$ njihovi navadi. Ugotovila sem, da če hočeš spremeniti druge, moraš najprej spremeniti sebe. Seminar je bil podan razumljivo, jasno, še posebej pa mi je bilo všeč, da je uporaben v praksi. Vaja dela mojstra.

- Zadovoljna sem s tem, da se je vsak posameznik lahko aktivno vkljucil v delo skupine. Spoznala sem, kdo sem, kako reagiram in kako me vidijo drugi.

- Navdušena sem, veliko ste pripomogli k spoznavanju samega sebe in odkrivanju vzrokov, zakaj so določene težave.

- Te vaje bi se lahko vpeljale že v osnovno šolo, da bi se mladi seznanili z njimi. Občutek imam, da bi marsikomu koristilo!
- Nadaljevati s takim izobraževanjem in doseči, da bo takšno izobraževanje v obveznem programu!

\section{Sklep}

S tem prispevkom sem želela poudariti, da mora uspešen model izobraževanja učiteljev za uspešnejšo komunikacijo vsebovati konkretne metode in pristope, ki bodo pomagali integrirati znanstvene in praktične teorije.

\section{Tatjana Kadunc,}

diplomirana pedagoginja

\section{Liferatura}

BECVAR, R. J. (1974): Skills for effective communication, A guide to building relationships, John Wiley and sons, New York, Sydney, Toronto, str. 79-95.

BROWN, G. (1975): Microteaching, A programme of teaching skills, Methven and Co. LTD, London.

BROWN, G., SHAW, M. (1986): Social skills training in education, Handbook of social skills, Pergamon Press, Oxford, New York, Beijing, Frankfurt, Sao Paolo, Sydney, Tokio, Toronto.

DOYLE, W. (1986): Classroom organization and management, Handbook of research on teaching, Ed. Wittrock, M. C. Macmillian Publishing Company, New York 1986, str. 392-431.

JACKSON, P. W. (1990): The function of educational research, Educational Research, 范, 5, str. 3-9.

JACQUES, S. D. (1984): Concepts in communication, International fundation for development alternatives, New York, San Francisco, London.

KADUNC, T., KUMELJ, N. (1988): Besedna in nebesedna komunikacija v razredu, Diplomska naloga, Filozofska fakulteta, Oddelek za pedagogiko, Ljubljana.

KLEINZING, M. G., FLODEN, R. E. (1987): Does cognitive psyhological research contribute to the improvement of teaching and teacher education, A critical review of recent developments. Paper presented at the 12 th Congress of the Association for teacher education in Europe (ATEE), West Berlin, September.

LAMOVEC, T. (1991): Spretnosti v medsebojnih odnosih, Zavod RS za produktivnost dela, Ljubljana.

LEINHART, G., GREENO, G. J. (1986): The cognitive skills of teaching, Journal of educational psychology, št. 5, str. 79-95.

MARENTIČ-POŽARNIK, B. (1987): Nova pota v izobraževanju učiteljev, DZS, Ljubljana.

SAGADIN, J. (1991): Razprave iz pedagoške metodologije, Znanstveni inštitut Filozofske fakuitete, Ljubljana.

SUGRUE, C. (1990): Teacher's knowledge as both the lock and key to professional development and planed change in the nineties, Testing a proposed framework. This paper has been prepared for presentation at the ATEE Conference in Limerick, August 1990. 